\title{
Simulating the effects of mean annual air-temperature changes on permafrost distribution and glacier size: an example from the Upper Engadin, Swiss Alps
}

\author{
Martin Hoelzle and Wilfried Haeberli \\ Laboratory of Hydraulics, Hydrology and Glaciology, Federal Institute of Technology (ETH), CH-8092 Zürich, Switzerland
}

\begin{abstract}
Models are developed to simulate changes in permafrost distribution and glacier size in mountain areas. The models exclusively consider equilibrium conditions. As a first application, the simplified assumption is used that one single parameter (mean annual air temperature) is changing.

Permafrost distribution patterns are estimated for a test area CorvatschFurtschellas) and for the whole Upper Engadin region (eastern Swiss Alps) using a relation between permafrost occurrence as indicated by BTS (bottom temperature of the winter snow cover) measurements, potential direct solar radiation and mean annual air temperature. Glacier sizes were assessed in the same region with data from the World Glacier Inventory database. The simulations for the glaciers are based on the assumption that an increase or decrease in equilibrium-line altitude (ELA) would lead to a mass-balance change. Model calculations for potential future changes in ELA and mass balance include estimated developments of area, length and volume. Mass changes were also calculated for the time period 1850-1973 on the basis of measured cumulative length change, glacier length and estimated ablation at the glacier terminus.

For the time period since 1850, permafrost became inactive or disappeared in about $15 \%$ of the area originally underlain by permafrost in the whole Upper Engadin region, and mean annual glacier mass balance was calculated as -0.26 to $-0.46 \mathrm{~m}$ w.e. $\mathrm{a}^{-1}$ for the larger glaciers in the same area. The estimated loss in glacier volume since 1850 lies between $55 \%$ and $66 \%$ of the original value. With an assumed increase in mean annual air temperature of $+3 \mathrm{C}$, the area of supposed permafrost occurrence would possibly be reduced by about $65 \%$ with respect to present-day conditions and only three glaciers would continue to partially exist.
\end{abstract}

\section{INTRODUCTION}

Consequences of changes in the climate system for the cryosphere at a regional scale are of special interest to people living in mountain areas. Indeed, changes in mountain cryospheric processes lead to massive landscape changes: not only permafrost and glaciers are involved, but also the water balance, snow-cover characteristics and growth conditions of the vegetation which are affected directly as well as indirectly through various feed-back mechanisms. There is a corresponding impact on the socio-economic conditions of people living in mountain areas, especially concerning tourism, one of the major sources of income in such areas. In addition, reduced slope stability could increase the hazard potential from rock slides and debris flows. Spatial modelling of glacier and permafrost occurrence in mountain areas as a function of climatic parameters could contribute to the early recognition of sensitive and sometimes dangerous areas.

Despite the still limited understanding of the complex processes involved, especially concerning the interactions between the atmosphere and mountain permafrost, an attempt is made to model permafrost distribution and glacier size in high mountain areas. The applied parameterization is built on a combination of empirical knowledge and physical considerations.

Investigations of the impact of atmospheric warming on permafrost should consider all the complex interactions between climate, microclimate and surface temperature. Regions in the discontinuous permafrost, with ground temperatures close to melting point, can be very sensitive to climate change (Thie, 1974). A climate change not only results in an increase of air temperature; precipitation, especially variations in snow-cover thickness and duration, can also lead to considerable changes in permafrost distribution. At depth, or if thick ice is present, the thermal reaction of the ground is strongly delayed with respect to changes in the atmosphere so that the response of permafrost is slow. Especially important is the ice content in the ground which delays the warming through latent heat of fusion involved with the melting or freezing process (Smith and Riseborough, 1983). Simple models and scenarios can 
nevertheless help to locate areas where near-surface changes in permafrost conditions may lead to such problems as thaw settlement, rock slides or debris flows.

In the area of the Upper Engadin (eastern Swiss Alps), discontinuous mountain permafrost and (mainly temperate, but in the ablation area slightly cold) glaciers exist in close proximity. An attempt to estimate roughly the change of both phenomena is made by assuming step changes between steady-state conditions as a first approximation.

\section{BASIC ASSUMPTIONS}

The parameterizations are based on available knowledge about the relation between climate and permafrost distribution in the Alps and on continuity considerations for glaciers. Equilibrium conditions are assumed throughout, i.e., non-stationary transitions were disregarded. A simulated perturbation was introduced with the change of one parameter only, in this case the mean annual air temperature. Full adjustment to such a perturbation is reached after a certain response time. The response time for mountain glaciers as given by the ratio between maximum ice depth and ablation at the terminus is typically a few decades (Haeberli and Hoelzle, 1995). The response time for permafrost, on the other hand, depends on the thermal conductivity, ice content and thickness of frozen ground (Osterkamp, 1983); for relatively warm and thin discontinuous permafrost it is typically measured in decades to centuries (Haeberli, 1990). The models used in the present study take into account neither such long-term response at greater depth below surface nor any feed-back mechanisms, and all climatic and surface parameters other than air temperature are kept unchanged. Such assumptions are quite unrealistic in nature. The corresponding model calculations nevertheless furnish important information about the sensitivity of the system and give interesting hints of especially sensitive areas.

\section{SCENARIOS AND DATABASE}

Four different steady-state conditons are used in this study: two for the future, one for today and one for the past. The future scenarios are based on scenario $\mathrm{A}$ of the Intergovernmental Panel on Climate Change (Houghton and others, 1990; cf. Swiss National Science Foundation, unpublished) which assumes mean annual air temperature in the years 2025 and 2100 to be $1.3^{\circ}$ and $3{ }^{\circ} \mathrm{C}$ higher than today. For the past scenario, a mean annual air temperature $0.6^{\circ} \mathrm{C}$ lower than today is assumed. Precipitation changes are not included at this stage.

The database for the regional existence of permafrost contains a large sample (Hoelzle and others, 1993) of bottom temperatures of the winter snow cover (BTS), which can be used as a good indicator of permafrost distribution (Haeberli and Patzelt, 1983; Keller and Gubler, 1993). For the glaciers the database is taken from a glacier inventory in this region recently updated by Maisch (1992; cf. Müller and others, 1976).
MODELLING PERMAFROST DISTRIBUTION AND GLACIER SIZE

\section{Permafrost}

Models developed in the Swiss Alps to estimate distribution patterns of discontinuous mountain permafrost are based on empirical considerations (Haeberli, 1975; Keller, 1992). In order to improve the physical basis for such estimates, the following new model was developed (Hoelzle and others, 1993) to simulate supposed permafrost distribution as a function of digital terrain information.

The more than 700 regionally available BTS measurements, representing the occurrence or absence of permafrost, are related to climatic factors. Therefore, mean annual air temperature was estimated for each BTS point using climate-station records together with a lapse rate of $0.56^{\circ} \mathrm{C}$ per $100 \mathrm{~m}$ for the Upper Engadin and $0.6^{\circ} \mathrm{C}$ per $100 \mathrm{~m}$ for the other areas (Gensler, 1978). In the same way, potential direct solar radiation (average daily means for the snow-free season, July-October) was calculated (Funk and Hoelzle, 1992) on the basis of a digital terrain model (DTM). The BTS measurements were then grouped into eight temperature classes from $-8^{\circ}$ to $0^{\circ} \mathrm{C}$ with steps of $1^{\circ} \mathrm{C}$. In this way, a correlation between BTS and potential direct solar radiation $\left(r^{2}=\right.$ 0.86 ), but not between mean annual air temperature and BTS $\left(r^{2}=0.002\right)$, was found (Hoelzle, 1992). This result emphasises the importance of short-wave direct solar radiation as the main variable local-scale energy source (Hoelzle, 1994) and also means that permafrost can exist at low-altitude sites as well, even at places where mean annual air temperature is positive if solar radiation is strongly reduced. From ground temperature measurements in shallow boreholes, BTS measurements, DC resistivity and seismic soundings (Bächler, 1930; Pancza, 1988; Vonder Mühll, 1993; paper in preparation by G. Wegmann), such low-altitude permafrost sites are, indeed, known to exist in the northern Swiss Alps and the Jura mountains. Inclusion of such low-altitude permafrost sites considerably enlarged the altitude range of documented permafrost occurrence and enabled the limit of permafrost existence (BTS between $-2^{\circ}$ and $-3^{\circ} \mathrm{C}$ ) to be described as a function of the two most important climatic factors, i.e. potential direct solar radiation and mean annual air temperature (Hoelzle and others, 1993; cf. Fig. 1). Although the relation may, in reality, be nonlinear, a linear model is used as a first approach in the investigated area. It should be kept in mind that the statistical relation used is locally calibrated and needs further testing for application in other areas.

The uncertainty with respect to estimates of mean annual air temperature is about $\pm 0.5^{\circ}$ to $\pm 0.6^{\circ} \mathrm{C}$. The model obviously works well for steep slopes, but is less reliable at the foot of slopes because the effects from longlasting accumulations of avalanche snow are not considered. The error range of the BTS measurements is about $\pm 0.5^{\circ} \mathrm{C}$. All BTS values are corrected for a standard snow-cover thickness of $1 \mathrm{~m}$ (Haeberli and Epifani, 1986) so that the influence of the snow-cover variability existing in Nature is essentially eliminated in the model. Areas with snow-cover thicknesses of less than $0.8 \mathrm{~m}$, such as, for example, rock walls, are thus probably 

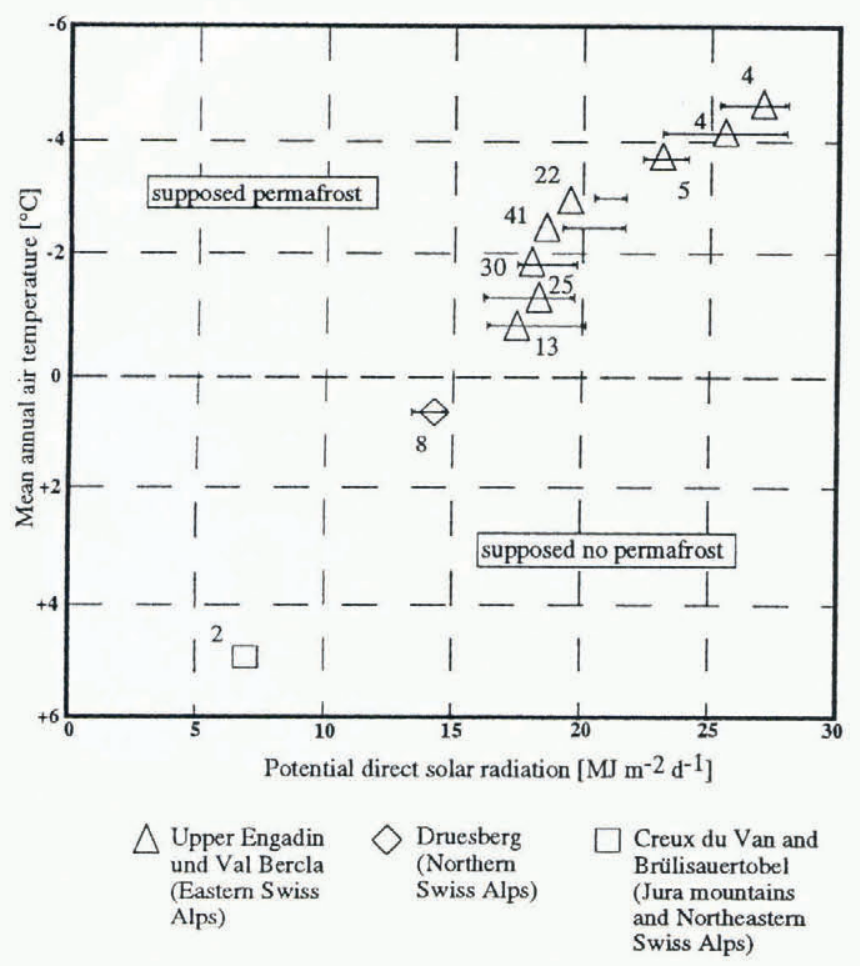

Fig. 1. Relation between potential direct solar radiation $(P R)$ and mean annual air temperature (MAAT) at the limit of permafrost existence (BTS between $-2^{\circ}$ and $-3^{\circ} \mathrm{C}$ : possible permafrost). The numbers represent the count of measurements. The symbols indicate mean values (PR and MAAT) in the given BTS class for altitude intervals of $100 \mathrm{~m}$. Double bars represent the range where indications of permafrost presence $\left(B T S<-3^{\circ} \mathrm{C}\right)$ and absence $\left(B T S>-2^{\circ} C\right)$ overlap.

colder than indicated by the applied relation. The simulations are highly sensitive with respect to the resolution of the DTM for calculating potential direct solar radiation. Higher resolution of the DTM with more precise determination of the surface topography leads to considerable improvements (see below).

For the different scenarios, the following changes in mean annual air temperature and local limit of permafrost occurrence were used:

$$
\begin{aligned}
& \text { Scenario I }=-0.6^{\circ} \mathrm{C}=-100 \mathrm{~m} \text { (decrease) } \\
& \text { Scenario II }=0.0^{\circ} \mathrm{C}=0 \mathrm{~m} \text { (increase) } \\
& \text { Scenario III }=+1.0^{\circ} \mathrm{C}=+170 \mathrm{~m} \text { (increase) } \\
& \text { Scenario IV }=+3.0^{\circ} \mathrm{C}=+500 \mathrm{~m} \text { (in }
\end{aligned}
$$

DTMs with two different mesh widths exist for the investigated area. One DTM was digitized from a 1:25000 map and interpolated to a regular $25 \mathrm{~m}$ grid. The other one is taken from a DTM for the whole of Switzerland (Rimini) with a mesh width of $100 \mathrm{~m}$. For both DTMs, four simulations were made with the abovedescribed scenarios. A comparison of the simulations with the different grid resolutions gives differing results. Considering permafrost distribution as a percentage of the whole investigation area, the DTMs with 100 and $25 \mathrm{~m}$ mesh width show differences between each scenario, which can reach up to $19 \%$ of the total permafrost area (see Table 1). These rather large differences can be explained by the quite different precision of the calculated potential direct solar radiation. Surface topography is much better represented in the $25 \mathrm{~m}$ than in the $100 \mathrm{~m}$ grid. More than 200 BTS measurements in the area show that results based on the $25 \mathrm{~m}$ grid are much more precise and give a quite realistic approach for present-day conditions (Hoelzle, 1994). Permafrost distribution modelled with the $100 \mathrm{~m}$ grid generally tends to overestimate permafrost occurrence.

Figure 2 shows the results of model simulations in the Corvatsch-Furtschellas area for the above-described scenarios I-IV based on the DTM with $25 \mathrm{~m}$ mesh width. The investigated area spans an altitude range of $1800-3500 \mathrm{~m}$ a.s.l. and has an areal extent of $16 \mathrm{~km}^{2}$ with supposed permafrost underlying about $29 \%$ of the total area today. Table 1 lists the results for the different scenarios and the corresponding percentages of the supposed permafrost and permafrost-free areas. In Figure 2 and Table 1 an interesting point can be seen: it is possible that, although increased air temperature induces both glacier and permafrost melt, new permafrost can develop in formerly glacierized areas. For example, Table 1 indicates that the area with supposed permafrost is about $33 \%$ of the total area for scenario I; in scenario II the corresponding area is $29 \%$, i.e. a reduction of only $4 \%$. On the other hand, there is a decrease in glacier area of about $6 \%$ and most of this originally glacier-covered

Table 1. Areas with and without supposed permafrost for different scenarios and digital terrain models. PF, supposed permafrost; NP, no permafrost supposed; GL, glacier area. 100\% means the whole area of the investigated region

Corvatsch-Furtschellas basis grid $100 \mathrm{~m}$ mesh width

Scenario I 1850

PF NP

$51 \%$
Scenario II 1990

$$
\text { Gl }
$$

$17 \%$

\begin{abstract}
PF
\end{abstract}
$48 \%$

\section{$N P$}

$41 \%$
Scenario III 2025

Gl

$11 \%$

\section{$P F \quad N P$}

$38 \%$

$60 \%$

Scenario IV 2100

$\begin{array}{lll}\text { PF } & \text { NP } & \text { Gl } \\ 15 \% & 85 \% & 0 \%\end{array}$

Corvalsch-Furtschellas basis grid $25 \mathrm{~m}$ mesh width

Scenario I 1850

PF NP

$33 \%$
Scenario II 1990

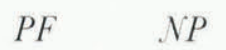

$29 \%$

$60 \%$
Scenario III 2025
Gl

$11 \%$

PF NP
$P F$
$28 \%$

\section{Gl}

$2 \%$

$15 \%$

Scenario IV 2100

PF $\quad$ NP

$10 \% \quad 90 \%$
Gl

$0 \%$ 


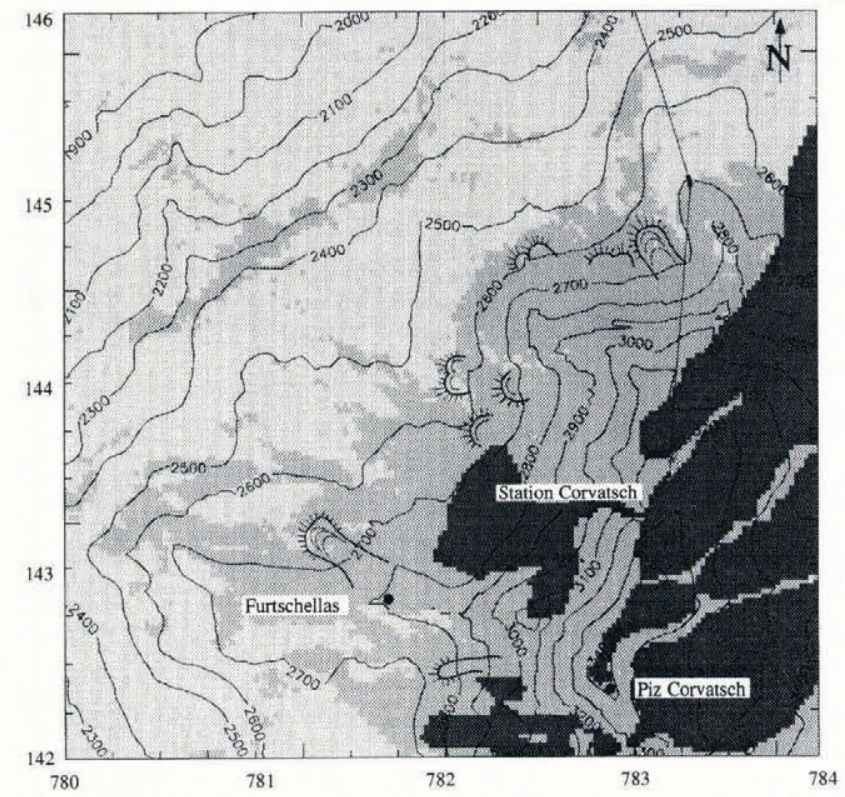

a

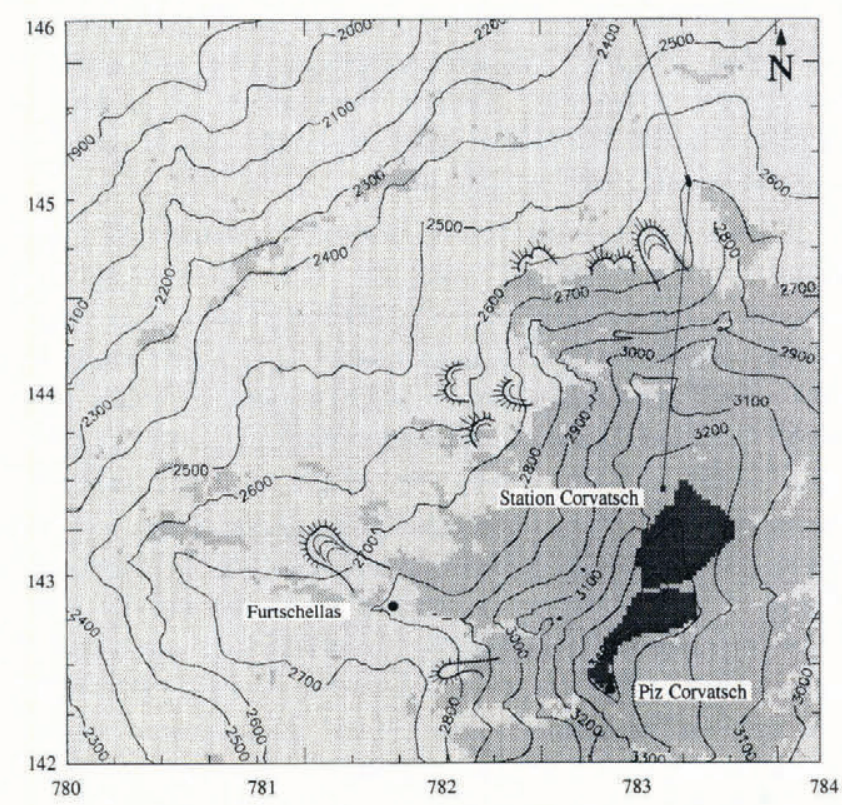

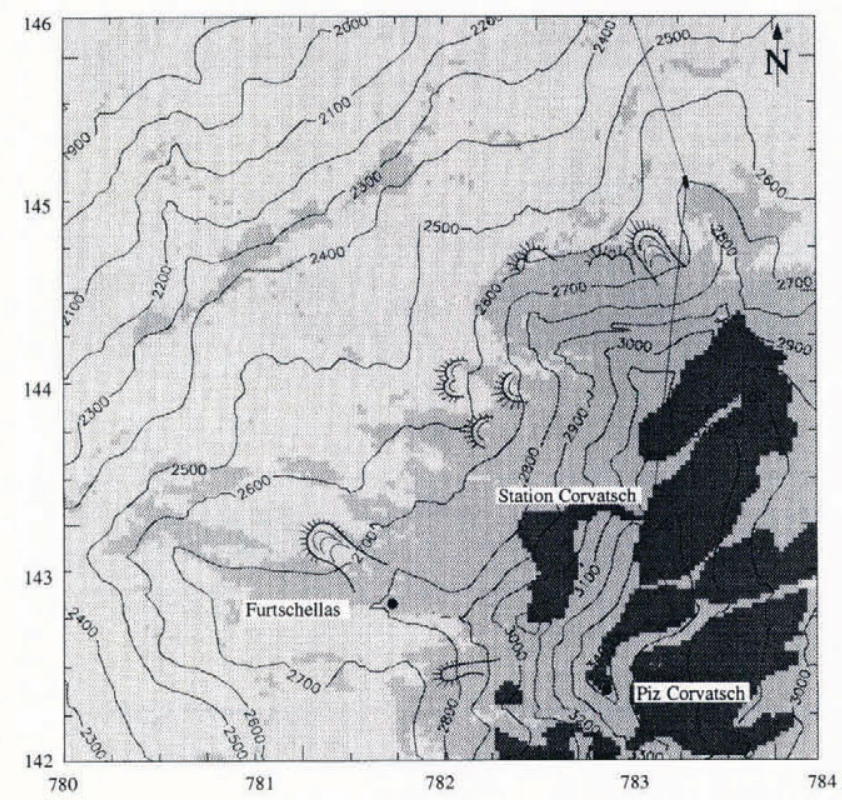

b

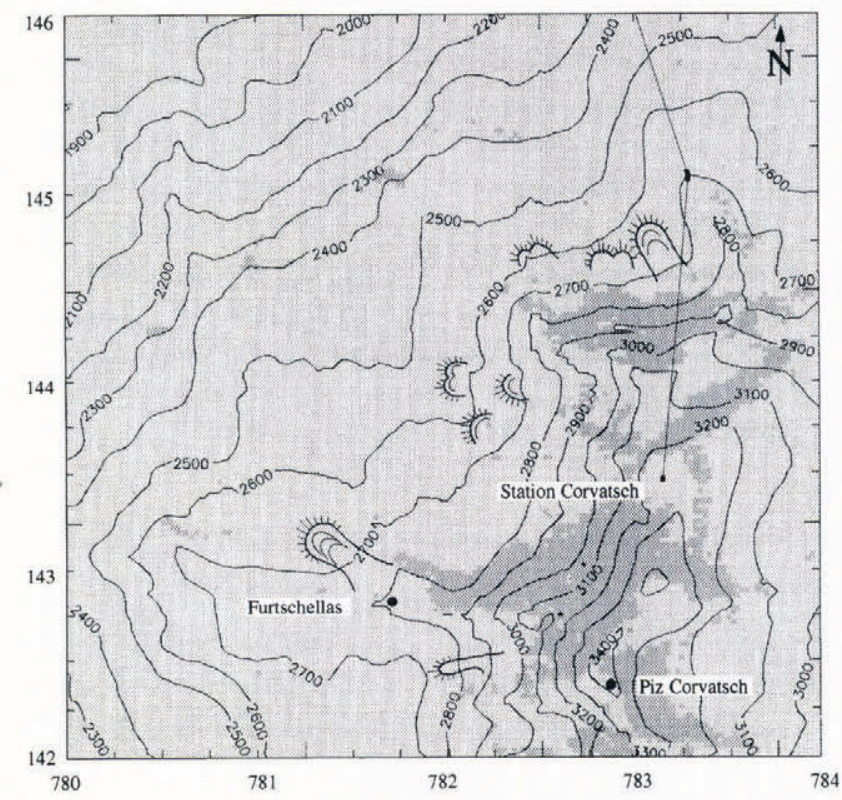

d

Fig. 2. Supposed area without permafrost (light grey) and supposed permafrost distribution (dark grey) in the CorvatschFurtschellas area, Upper Engadin, after a. scenario I (1850), with glacier area 1850 (black) reconstructed by Maisch (1992); b. scenario II (1990), with glacier area 1973 (black) close to the glacier extent of 1990 after Maisch (1992); c. scenario III (2025) showing glacier area 2025 (black), with glacier length calculated as described in the text, the area adjusted by hand; d. scenario IV (2100), with no glaciers.

terrain will change now into permafrost area. Such a phenomenon can exist in reality as tested in one area with BTS measurements; permafrost can indeed be detected, but the permafrost aggradation could be due to the maintenance of a ski-run, inducing increased heat loss through compacted snow. Subglacial permafrost may exist beneath the margins of smaller vanishing glaciers which can be partly cold in the ablaiiton area (Haeberli, 1975), but such occurrences are thought to be of limited extent. Concerning the region of the Upper Engadin, the change in permafrost area is calculated as $-65 \%$ between scenarios II and IV.

\section{GLACIERS}

On the basis of a parameterization scheme (Hoelzle, 1994; Haeberli and Hoelzle, 1995) for a database of 62 glaciers in the Upper Engadin region (catchment of the river Inn), different glacier characteristics are estimated. The database to which the parameterization is applied consists of the following data: area in 1850, area in 1973; length in 1850, length in 1973; altitude: maximum, median, minimum in 1850, minimum in 1973 (see Table 2). As a first step, volume decrease between 1850 and 1973 is assessed by deriving a step change in mass balance $(\delta b)$ between two 
Table 2. Selected glacier data from the inventory of Maisch (1992), which are the basis for the glacier parameterization in the Upper Engadin region

\begin{tabular}{|c|c|c|c|c|c|c|c|c|}
\hline Glacier & $\begin{array}{c}\text { Area } 1973 \\
\mathrm{~km}^{2}\end{array}$ & $\begin{array}{c}\text { Area } 1850 \\
\mathrm{~km}^{2}\end{array}$ & $\begin{array}{c}\text { Length } 1973 \\
\mathrm{~km}\end{array}$ & $\begin{array}{c}\text { Length } 1850 \\
\mathrm{~km}\end{array}$ & $\begin{array}{c}H_{\mathrm{Max}} 1973 \\
\text { m a.s.l. }\end{array}$ & $\begin{array}{c}H_{\mathrm{Med}} 1973 \\
\text { m a.s.l. }\end{array}$ & $\begin{array}{c}H_{\text {Min }} 1973 \\
\text { m a.s.l. }\end{array}$ & $\begin{array}{r}H_{\mathrm{Min}} 1850 \\
\mathrm{~m} \text { a.s.l. }\end{array}$ \\
\hline Morteratsch & 16.401 & 19.251 & 7.00 & 8.90 & 3900 & 3000 & 2100 & 1910 \\
\hline Tschierva & 6.198 & 7.633 & 4.75 & 5.85 & 3980 & 3025 & 2190 & 2060 \\
\hline Roseg & 8.522 & 11.076 & 4.90 & 6.85 & 3560 & 3060 & 2240 & 2080 \\
\hline Corvatsch & 0.656 & 1.197 & 0.95 & 1.95 & 3440 & 3145 & 2820 & 2550 \\
\hline Tremoggia & 2.498 & 3.407 & 2.50 & 2.90 & 3330 & 2995 & 2600 & 2400 \\
\hline Fex & 1.330 & 2.453 & 1.55 & 3.15 & 3340 & 2795 & 2350 & 2120 \\
\hline Fedoz & 2.493 & 3.314 & 2.55 & 4.15 & 3360 & 2950 & 2500 & 2130 \\
\hline D'Agnel & 1.218 & 2.355 & 1.30 & 2.55 & 3170 & 2945 & 2790 & 2480 \\
\hline Calderas & 1.183 & 1.593 & 1.80 & 2.70 & 3290 & 3065 & 2710 & 2530 \\
\hline
\end{tabular}

steady-state conditions, i.e. after full dynamic response, from the incurred cumulative length change $(\delta l)$ between 1850 and 1973 as determined from aerial photography, field investigations and available maps (Maisch, 1992), the mass balance at the terminus $\left(b_{\mathrm{t}}\right)$ and glacier length $(L)$ : $\delta b \approx \delta l \cdot b_{\mathrm{t}} / L$. Values for $\delta l$ of the investigated glaciers range between 0.5 and $2.0 \mathrm{~km}$. The mass balance (ablation) at the tongue $b_{\mathrm{t}}$ is determined by assuming a mass-balance gradient $\mathrm{d} b / \mathrm{d} h$ in the ablation area of $0.75 \mathrm{~m} \mathrm{a}^{-1}$ per $100 \mathrm{~m}$ and considering the vertical extent between median and minimum altitude $\left(\mathrm{d} h_{\mathrm{M}}\right): b_{\mathrm{t}} \approx(\mathrm{d} b / \mathrm{d} h) \cdot \mathrm{d} h_{\mathrm{M}}$. This parameter $\left(b_{t}\right)$ induces the largest uncertainty of the estimation, because Alpine mass-balance gradients may vary within a range of $0.4-1.0 \mathrm{~m} \mathrm{a}^{-1}$ per $100 \mathrm{~m}$. The error range of massbalance changes calculated for individual glaciers may, therefore, exceed $\pm 30 \%$. For the volume change, mean annual mass balance is calculated as $\bar{b}=\delta b / 2$. The response time $t_{\mathrm{r}}$ for each glacier is derived from the ratio between maximum thickness of the glacier ( $\left.d_{\text {Max }}\right)$ and $b_{\mathrm{t}}: t_{\mathrm{r}} \approx d_{\mathrm{Max}} / b_{\mathrm{t}} \quad$ (Jóhannesson and others, 1989). One problem concerns the fact that the response time of each glacier does not exactly correspond to the considered time interval. Therefore, two estimates for the mean mass balance $\bar{b}$ were calculated (see Table 3 ). The first one $\left(\bar{b}_{1}\right)$ is based on a theoretical count of response times for each glacier since 1850. This number probably represents the maximum number of full dynamic responses each glacier could have had since 1850. In reality, most glaciers had only one near-steady-state condition between 1890 and 1920. Hence, the second mean mass balance $\left(\bar{b}_{2}\right)$ is based on two response times only. Determination of mean mass balance with these two approaches probably gives more or less the possible range of realistic mean secular mass balances for each glacier.

Geodetic photogrammetric measurements covering long time periods show that the mean mass balance

Table 3. Parameters calculated for the reconstruction concerning some larger glaciers in the investigated area of the Upper Engadin

\begin{tabular}{|c|c|c|c|c|c|c|c|c|}
\hline \multirow[t]{2}{*}{ Glacier } & $\delta l$ & $b_{\mathrm{t}}$ & $\delta b$ & $\bar{b}_{1}$ & $\bar{b}_{2}$ & $d_{\text {Max }}$ & $t_{\mathrm{r}}$ & $\begin{array}{l}\text { Count of } t_{\mathrm{r}} \\
\text { since } 1850\end{array}$ \\
\hline & $\mathrm{km}$ & $\mathrm{m}$ & $\mathrm{m}$ & $\mathrm{m}$ & $\mathrm{m}$ & $\mathrm{m}$ & $\mathrm{a}$ & \\
\hline Morteratsch & 1.9 & 6.8 & 1.8 & 0.29 & 0.45 & 265 & 39.2 & 3.1 \\
\hline Tschierva & 1.1 & 6.3 & 1.4 & 0.18 & 0.36 & 192 & 30.6 & 4.0 \\
\hline Roseg & 1.9 & 6.2 & 2.5 & 0.31 & 0.61 & 192 & 31.2 & 3.9 \\
\hline Corvatsch & 1.0 & 2.4 & 2.6 & 0.23 & 0.64 & 53 & 21.9 & 5.6 \\
\hline Tremoggia & 0.4 & 3.0 & 0.5 & 0.07 & 0.12 & 106 & 35.7 & 3.4 \\
\hline Fex & 1.6 & 3.3 & 3.5 & 0.42 & 0.86 & 100 & 30.0 & 4.1 \\
\hline Fedoz & 1.6 & 3.4 & 2.1 & 0.37 & 0.53 & 145 & 43.0 & 2.9 \\
\hline D'Agnel & 1.2 & 1.2 & 1.1 & 0.35 & 0.28 & 89 & 76.9 & 1.6 \\
\hline Calderas & 0.9 & 2.7 & 1.3 & 0.15 & 0.33 & 75 & 28.3 & 4.3 \\
\hline Mean $(n=9)$ & 1.3 & 3.9 & 1.9 & 0.26 & 0.47 & 135 & 37.4 & 3.7 \\
\hline S.d. & 0.5 & 2.0 & 0.9 & 0.11 & 0.22 & 69 & 16.0 & 1.1 \\
\hline $\begin{array}{l}\text { Mean for all } \\
\text { glaciers }(n=62)\end{array}$ & 0.6 & 1.5 & 0.9 & 0.17 & 0.23 & 62 & 58.2 & 3.2 \\
\hline S.d. for all glaciers & 0.4 & 1.4 & 0.7 & 0.11 & 0.17 & 48 & 47.7 & 1.9 \\
\hline
\end{tabular}


since about 1880 for six Alpine glaciers varies between -0.19 and $-0.57 \mathrm{mw}$.e. $\mathrm{a}^{-1}$ (Finsterwalder and Rentsch, 1981; Haeberli, 1991). Assier (1993) reports a value for the secular mean mass balance for glaciers in the Southern Alps of $-0.22 \mathrm{~m}$ w.e. $\mathrm{a}^{-1}$. The mean value from the present investigation of 62 glaciers in the Upper Engadin is $\bar{b}_{1}=$ $-0.17 \mathrm{~m}$ w.e. $\mathrm{a}^{-1}$ and $\bar{b}_{2}=-0.23 \mathrm{~m}$ w.e. $\mathrm{a}^{-1}$. For the larger glaciers in the area, where overall mass losses are less limited by glacier size, the range is slightly higher, i.e. $\bar{b}_{1}=$ $-0.26 \mathrm{~m}$ w.e. $\mathrm{a}^{-1}$ and $\bar{b}_{2}=0.46 \mathrm{~m}$ w.e. $\mathrm{a}^{-1}$ (Table 3 ). These calculated results agree quite well with the measured data. With the so-estimated mean mass balance and a mean area between 1850 and 1973, glacier mass loss in the Upper Engadin is estimated at $-55 \%$ to $-65 \%$ for the larger glaciers (Table 4), which in fact clearly dominate the sample of all glaciers: more than $90 \%$ of the estimated total volume in 1973 (62 glaciers) is contained in the nine selected larger glaciers.

Looking into future glacier behaviour as a reaction to potential climate change, Kuhn (1990) investigated different parameters and their influence on a possible ELA shift. This author concluded that the influence of air temperature, considering also feed-back mechanisms, on the shift of ELA for a temperature increase of $\pm 1^{\circ} \mathrm{C}$ is about $\pm 170 \mathrm{~m}$. Concerning the sensitivity of each glacier with respect to such an ELA shift, a rough distinction can be made between a climatic-regional- and a localtopography (hypsography)-caused part. The climaticregional sensitivity is given by the mass-balance change, which can be expressed as the product of the mass-balance gradient $\mathrm{d} b / \mathrm{d} h$ and an ELA shift $\delta \mathrm{ELA}$ $\delta b \approx \delta \mathrm{ELA} \cdot(\mathrm{d} b / \mathrm{d} h)(\mathrm{Kuhn}, 1981)$. With regard to the future existence/extinction of glaciers, the questions must be considered whether (1) anticipated length change for a given mass-balance forcing exceeds the present length, and/ or (2) the ELA may shift over the highest altitude of the glacier. With ELA shifting upwards by $500 \mathrm{~m}$, for instance, 59 of the 62 glaciers in the Upper Engadin region would disappear and only the higher parts of the three largest glaciers (Tschierva, Roseg and Morteratsch) could survive the 21 st century, assuming scenario IV as defined above.

\section{CONGLUSIONS}

The new model for simulating permafrost occurrence enables more detailed calculations as well as the inclusion of low-altitude permafrost sites. However, parameterization of the inventoried glaciers is still based on better knowledge than exists with regard to mountain permafrost. A simple parameterization can be realised with some restrictions for large glacier-inventory data sets. As an example, mean annual mass losses of the glaciers in the Upper Engadin region are estimated at about -0.17 to $0.23 \mathrm{~m}$ w.e. $\mathrm{a}^{-1}$ for all glaciers, with a tendency to higher values for larger glaciers $\left(-0.26\right.$ and $-0.46 \mathrm{~m}$ w.e. $\left.\mathrm{a}^{-1}\right)$. Such values compare favourably with results from longterm measurements.

The sensitivity of the mountain cryosphere with respect to potential changes is investigated by applying Houghton and others' (1990) scenario A with respect to mean annual air temperature. The simulations show that important local-scale changes can occur in the mountain cryosphere: from 1990 to $2100,65 \%$ of the permafrost area could start degrading and possibly only three out of 62 presently existing glaciers would survive this warming scenario.

The basis of such simulations needs considerable improvement. In particular, the relation between the atmosphere and the permafrost in mountain areas should be better understood. This can only be achieved with an intensive measurement programme concerning the energy-balance components involved.

\section{AGKNOWLEDGEMENTS}

The present study was carried out as part of the Swiss National Research Programme on Climate Change and Natural Catastrophes through project No. 4031-34232 with funds from the National Science Foundation. Special thanks are due to many colleagues of the Laboratories of Hydraulics, Hydrology and Glaciology at ETH Zürich for reviewing the manuscript.

Table 4. Reconstruction of the volume change since 1850 with the estimation of two different mean mass balances

\begin{tabular}{|c|c|c|c|c|c|}
\hline Glacier name & $\begin{array}{l}\text { Volume } 1973 \\
10^{6} \mathrm{~m}^{3} \text { w.e. }\end{array}$ & $\begin{array}{l}\text { Volume change } \bar{b}_{1} \\
\qquad 10^{6} \mathrm{~m}^{3} \text { w.e. }\end{array}$ & $\begin{array}{c}\text { Volume change } \bar{b}_{2} \\
10^{6} \mathrm{~m}^{3} \text { w.e. }\end{array}$ & $\begin{array}{c}\text { Volume change } \bar{b}_{1} \\
\%\end{array}$ & $\begin{array}{c}\text { Volume change } \bar{b}_{2} \\
\%\end{array}$ \\
\hline Morteratsch & 932 & 636 & 1003 & 41 & 52 \\
\hline Tschierva & 249 & 153 & 308 & 38 & 55 \\
\hline Roseg & 416 & 374 & 738 & 47 & 64 \\
\hline Corvatsch & 9 & 26 & 73 & 74 & 89 \\
\hline Tremoggia & 78 & 25 & 43 & 24 & 36 \\
\hline Fex & 27 & 98 & 201 & 78 & 88 \\
\hline Fedoz & 77 & 132 & 189 & 63 & 71 \\
\hline D'Agnel & 22 & 77 & 62 & 78 & 74 \\
\hline Calderas & 28 & 26 & 57 & 48 & 67 \\
\hline Sum $(n=9)$ & 1840 & 1547 & 2674 & & \\
\hline Mean & & & & 55 & 66 \\
\hline $\begin{array}{l}\text { Sum for all glaciers }(n=62) \\
\text { Mean for all glaciers }\end{array}$ & 2035 & 1965 & 3182 & 68 & 73 \\
\hline
\end{tabular}




\section{REFERENCES}

Assier, A. 1993. L'englacement des Alpes du Sud Franco-Italiennes du petit âge de glace à la fin du XXième siècle. (Thèse du doctorat, Institut de Géographie Alpine, Grenoble.

Bächler, E. 1930. Der verwünschte oder verhexte Wald im Brüeltobel. Appenzellerkalender, 209.

Finsterwalder, R. and H. Rentsch. 1980. Zur Höhenänderung von Ostalpengletschern im Zeitraum 1969-1979. Z. Glelscherkd. Glazialgeol.. 16, 111-115.

Funk, M. and M. Hoelzle. 1992. Application of a potential direct solar radiation model for investigating occurrences of mountain permafrost. Permafrost and Periglacial Processes, 3 2), 139-142

Gensler, G. A. 1978. Das Klima von Graubünden. Schweiz. Meteorol. Zentralanstall, 112. Habilitationsschrift an der Universität Zürich.)

Haeberli, W. 1975. Untersuchungen zur Verbreitung von Permafrost zwischen Flüelapass und Piz Grialetsch (Graubünden). Eidg. Tech. Hochschule, Zürich. Versuchsanst. Wasserbau, Hydrol., Glaziol. Mitt. 17.

Haeberli, W. 1976. Eistemperaturen in den Alpen. Z. Gletscherkd. Glazialgeol., 11 (2), 203-220.

Haeberli, W. 1990. Glacier and permafrost signals of 20th-century warming. Ann. Glaciol., 14, 99-101.

Haeberli, W. 1991. Alpengletscher im Treibhaus der Erde. Regio Basil, $32(2), 59-72$.

Haeberli, W. and F. Epifani. 1986. Mapping the distribution of buried glacier ice: an example from Lago delle Locce, Monte Rosa, Italian Alps. Ann. Glaciol., 8, 78-81.

Haeberli, W. and M. Hoelzle. 1995. Application of inventory data for estimating characteristics of and regional climate-change effects on mountain glaciers: a pilot study with the European Alps. Ann. Glaciol., 21 (see paper in this volume).

Haeberli, W. and G. Patzelt. 1983. Permafrostkartierung im Gebiet der Hochebenkar-Blockgletscher, Obergurgl, Ötztaler Alpen. Z. Gletscherkd. Glazialgeol., 17, 127-150.

Hoelzle, M. 1992. Permafrost occurrence from BTS measurements and climatic parameters in the eastern Swiss Alps. Permafrost and Periglacial Processes, 3(2), 143-147.

Hoelzle, M. 1994. Permafrost und Gletscher im Oberengadin: Grundlagen und Anwendungsbeispiele für automatisierte Schätzverfahren. Eidg. Tech. Hochschule, Zürich. Verzuchsanst. Wasserbau, Hydrol., Glaziol. Mitt. 132.

Hoelzle, M., W. Hacberli and F. Keller, 1993. Application of BTSmeasurements for modelling mountain permafrost distribution. In Permafrost. Sixth International Conference. Proceedings (Vol. 1). July 5-9, 1993, Beijing, China. Guangzhou, South China University of Technology Press, 272-277.

Houghton, J. T., G.J. Jenkins and J.J. Ephraums. 1990. Climate change: the IPCC scientific assessment. Cambridge, etc., Cambridge University Press.

Johannesson, T., C. Raymond and E. Waddington. 1989. Time-scale for adjustment of glaciers to changes in mass balance. J. Glaciol., 35 (121), 355-369.

Keller, F. 1992. Automated mapping of mountain permafrost using the program PERMAKART within the geographical information system ARC/INFO. Permafrost and Periglacial Processes, 3 2), 133-138.

Keller, F. and H. Gubler. 1993. Interaction between snow cover and high mountain permafrost, Murtèl-Corvatsch, Swiss Alps. In Permafrost. Sixth International Conference. Proceedings (Vol. 1). July 5-9, 1993, Beijing, China. Guangzhou, South China University of Technology Press, 332-337.

Kuhn, M. 1981. Climate and glaciers. International Association of Hydrological Sciences Publication 131 (Symposium at Canberra 1979 - Sea Level, Ice and Climatic Change), 3-20.

Kuhn, M. 1990. Energieaustausch Atmosphäre. Eidg. Tech. Hochschule, Zürich. Versuchsanst. Wasserbau, Hydrol., Glaziol. Mitt. 108, 21-32.

Maisch, M. 1992. Die Gletscher Graubündens: Rekonstruktionen und Auswertung der Gletscher und deren Veränderungen seit dem Hochstand von $1850 \mathrm{im}$ Gebiet der östlichen Schweizer Alpen. Teil A: Grundlagen-Analysen - Ergebnisse. Zürich, Geographisches Institut der Universität Zürich.

Müller, F. T. Caflisch and G. Müller. 1976. Fïrn und Eis der Schweizer Alpen: Gletscherinventar. Zürich, Eidgenössische Technische Hochschule.

Osterkamp, T.E. 1983. Response of Alaskan permafrost to climate. In Permafrost. Fourth International Conference. Final proceedings, July 17-22, 1983, Fairbanks, Alaska. Washington, DC, National Academy Press, $145-152$.

Pancza, A. 1988. Un pergélisol actuel dans le Jura Neuchâtelois. Bull. Soc. Neuchâtel Géogr. 32/33, $129-140$.

Smith, M. W. and D. W. Riseborough. 1983. Permafrost sensitivity to climatic change. In Permafrost. Fourth International Conference. Final proceedings, July 17-22, 1983, Fairbanks, Alaska. Washington, DC, National Academy Press, 1178-1183.

Swiss National Science Foundation. Unpublished. Mögliche Szenarien als Grundlage für die Forschungsarbeiten im Rahmen des NFP 31. Bern, Swiss National Science Foundation. (Internal Report Nationales Forschungsprogramm "Klimaänderungen und Naturkatastrophen".)

Thie, J. 1974. Distribution and thawing of permafrost in the southern part of the discontinuous zone in Manitoba. Arctic, 27 (3), 189-200.

Vonder Mühll, D. 1993. Geophysikalische Untersuchungen im Permafrost des Oberengadins. Eidg. Tech. Hochschule, Zürich. Versuchsanst. Wasserbau, Hydrol., Glaziol. Mitt. 122.

Wegmann, G. 1995. Untersuchungen zu sporadischen Permafrostvorkommen auf geringer Meereshöhe in den nördlichen Schweizer Alpen. (Diplomarbeit, Eidgenössische Technische Hochschule, Zürich. Versuchsanstalt für Wasserbau, Hydrologie und Glaziologie.) 